\title{
Validation List no. 89 \\ Validation of publication of new names and new combinations previously effectively published outside the IJSEM
}

\begin{abstract}
The purpose of this announcement is to effect the valid publication of the following new names and new combinations under the procedure described previously [Int J Syst Bacterio/ 27(3), iv (1977)]. Authors and other individuals wishing to have new names and/or combinations included in future lists should send the pertinent reprint or a photocopy thereof to the IJSEM Editorial Office for confirmation that all of the other requirements for valid publication have been met. It should be noted that the date of valid publication of these new names and combinations is the date of publication of this list, not the date of the original publication of the names and combinations. The authors of the new names and combinations are as given below, and these authors' names will be included in the author index of the present issue and in the volume author index. Inclusion of a name on these lists validates the name and thereby makes it available in bacteriological nomenclature. The inclusion of a name on this list is not to be construed as taxonomic acceptance of the taxon to which the name is applied. Indeed, some of these names may, in time, be shown to be synonyms, or the organisms may be transferred to another genus, thus necessitating the creation of a new combination.
\end{abstract}

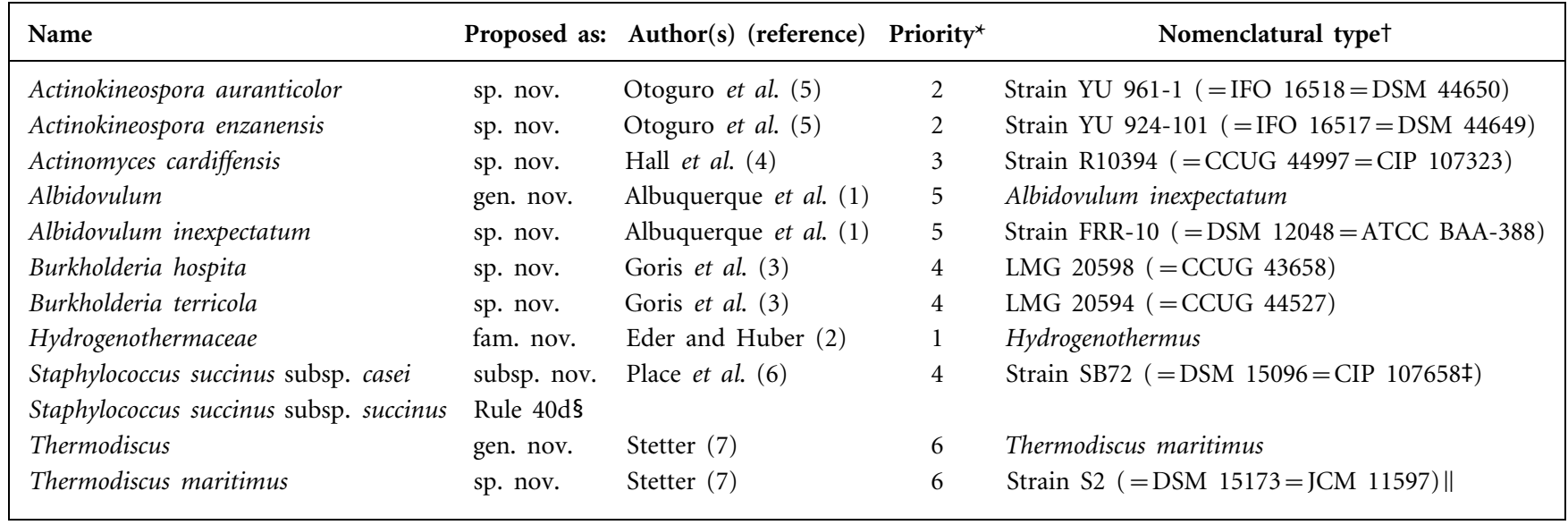

For references to Validation Lists 1-71, see Int J Syst Bacteriol 49 (1999) 1325. Lists 72-88 were published in Int J Syst Evol Microbiol 50 (2000) 3, 423, 949, 1415, 1699, 1953; 51 (2001) 1, 263, 793, 1229, 1619, 1945; and 52 (2002) 3, 685, 1075, 1437, 1915.

${ }^{\star}$ Priority number assigned according to the date the documentation and request for validation are received.

†Abbreviations: ATCC, American Type Culture Collection, Manassas, VA, USA; CIP, Collection of the Institute Pasteur, Paris, France; CCUG, Culture Collection, University of Göteborg, Göteborg, Sweden; DSM, DSMZ - Deutsche Sammlung von Mikroorganismen und Zellkulturen GmbH, Braunschweig, Germany; IFO, Institute for Fermentation, Osaka, Japan; JCM, Japan Collection of Microorganisms, RIKEN, Saitama, Japan; LMG, LMG Culture Collection, Universiteit Gent, Gent, Belgium.

†R. Place, personal communication.

§According to Rule 40d (formerly Rule 46) of the International Code of Nomenclature of Bacteria, the valid publication of Staphylococcus succinus subsp. casei automatically creates another subspecies, Staphylococcus succinus subsp. succinus Lambert et al. 1998.

\|Designated as the type strain (in the effective publication 'deposited strain') and culture collection accession numbers provided on request for validation. 


\section{References}

1. Albuquerque, L., Santos, J., Travassos, P., Nobre, M. F., Rainey, F. A., Wait, R., Empadinhas, N., Silva, M. T. \& da Costa, M. S. (2002). Albidovulum inexpectatum gen. nov., sp. nov., a nonphotosynthetic and slightly thermophilic bacterium from a marine hot spring that is very closely related to members of the photosynthetic genus Rhodovulum. Appl Environ Microbiol 68, 4266-4273.

2. Eder, W. \& Huber, R. (2002). New isolates and physiological properties of the Aquificales and description of Thermocrinis albus sp. nov. Extremophiles 6, 309-318.

3. Goris, J., Dejonghe, W., Falsen, E., De Clerck, E., Geeraerts, B., Willems, A., Top, E. M., Vandamme, P. \& De Vos, P. (2002). Diversity of transconjugants that acquired plasmid pJP4 or pEMT1 after inoculation of a donor strain in the A- and B-horizon of an agricultural soil and description of Burkholderia hospita sp. nov. and Burkholderia terricola sp. nov. Syst Appl Microbiol 25, 340-352.

4. Hall, V., Collins, M. D., Hutson, R., Falsen, E. \& Duerden, B. I. (2002). Actinomyces cardiffensis sp. nov. from human clinical sources. J Clin Microbiol 40, 3427-3431.

5. Otoguro, M., Hayakawa, M., Yamazaki, T., Tamura, T., Hatano, K. \& limura, Y. (2001). Numerical phenetic and phylogenetic analyses of Actinokineospora isolates, with a description of Actinokineospora auranticolor sp. nov. and Actinokineospora enzanensis sp. nov. Actinomycetologica 15, 30-39.

6. Place, R. B., Hiestand, D., Burri, S. \& Teuber, M. (2002). Staphylococcus succinus subsp. casei subsp. nov., a dominant isolate from surface ripened cheese. Syst Appl Microbiol 25, 353-359.

7. Stetter, K. O. (2001). Genus VII. Thermodiscus gen. nov. In Bergey's Manual of Systematic Bacteriology, 2nd edn, vol. 1 (The Archaea and the Deeply Branching and Phototrophic Bacteria), pp. 189-190. Edited by D. R. Boone, R. W. Castenholz \& G. M. Garrity. New York: Springer. 